\title{
Investigation of the Relationship Between Fok1 and Col1A1 Gene Polymorphisms and Development of Treatment-Related Bone Complications in Children with Acute Lymphoblastic Leukemia
}

\author{
Akut Lenfoblastik Lösemili Çocuklarda Fok1 ve Col1A1 Gen Polimorfizmleri ile Tedaviye \\ Bağı Kemik Komplikasyonlarının Gelişimi Arasındaki Ilişkinin Araştııııması
} \begin{abstract}
(D) Hale Ören 1
${ }^{1}$ Dokuz Eylül University Faculty of Medicine, Department of Pediatric Hematology, Izmir, Turkey

2Dokuz Eylül University Faculty of Medicine, Department of Medical Biology, Izmir, Turkey

${ }^{3}$ Dokuz Eylül University Facullty of Medicine, Department of Pediatrics, Izmir, Turkey
\end{abstract}

(D) Melek Erdem¹, (D) Özlem Tüfekçi¹, (D) Sefa Kızıldağ2 , (D) Şebnem Yılmaz¹, (D) Deniz Kızmazoğlu1, (D) Berna Eroğlu Filibeli3,

\section{Abstract}

\begin{abstract}
Objective: In acute lymphoblastic leukemia (ALL), various clinical risk factors and genetic predispositions contribute to the development of bone complications during and after chemotherapy. In this study, we aimed to investigate whether vitamin $\mathrm{D}$ receptor (VDR) Fok1 and collagen protein Col1A1 Sp1-binding site gene polymorphisms, which are important in bone mineral and matrix formation, have effects on the development of bone abnormalities in childhood ALL survivors.
\end{abstract}

Materials and Methods: Fifty children with ALL who were treated with the ALL Berlin-Frankfurt-Muenster-95 protocol between 1998 and 2008 and were followed for at least 7 years were enrolled. The control group consisted of 96 healthy children. VDR Fok1 and Col1A1 Sp1-binding site gene polymorphisms were analyzed by polymerase chain reaction and restriction fragment length polymorphism. Bone mineral density (BMD) and markers of bone metabolism were all noted. All patients who presented with pain in the joints were examined for bone pathologies while on chemotherapy or during long-term follow-up.

Results: Low BMD (16\%), osteoporosis (12\%), and osteonecrosis $(8 \%)$ were present in a total of 18 patients (36\%). The frequency of osteonecrosis and total bone abnormalities was significantly higher in children aged $\geq 10$ years $(p=0.001)$. The risk of low BMD and osteonecrosis was higher in those with vitamin D deficiency. Only the Col1A1 Sp1-binding site gene polymorphism showed a significant association in ALL patients with osteonecrosis.

Conclusion: The development of therapy-induced bone mineral loss and osteonecrosis in children with ALL is frequent and the risk is especially higher in children aged $\geq 10$ years and with vitamin D deficiency. The association between Col1A1 Sp1-binding site gene polymorphisms and osteonecrosis has to be assessed in a larger group of ALL survivors.

Keywords: Acute lymphoblastic leukemia, Bone mineral density, Genetic polymorphism, Osteonecrosis, Osteoporosis
Öz

Amaç: Akut lenfoblastik lösemide (ALL), çeşitli klinik risk faktörleri ve genetik yatkınlıklar kemoterapi sırasında ve sonrasında kemik komplikasyonlarının gelişmesine katkıda bulunur. Bu çalışmada, kemik mineral ve matriks oluşumunda önemli olan $D$ vitamini reseptörü (VDR) Fok1 ve kollajen proteini Col1A1 Sp1 bağlayıcı bölge gen polimorfizmlerinin, ALL'den sağ kalan çocuklarda kemik anormalliklerinin gelişimine etkilerinin olup olmadığını araştırmayı amaçladık.

Gereç ve Yöntemler: 1998-2008 yılları arasında ALL tanısı alıp, ALL Berlin-Frankfurt-Muenster-95 protokolü ile tedavi edilen ve en az 7 yıl takip edilen 50 çocuk çalışmaya dahil edildi. Kontrol grubu 96 sağlıklı çocuktan oluşuyordu. VDR Fok1 ve Col1A1 Sp1 bağlayıcı bölge gen polimorfizmleri polimeraz zincir reaksiyonu ve restriksiyon fragman uzunluğu polimorfizmi ile analiz edildi. Kemik mineral yoğunluğu (KMY) ve kemik metabolizması belirteçleri kaydedildi. Eklemlerde ağrı ile başvuran tüm hastalar kemoterapi veya uzun süreli takip sırasında kemik patolojileri açısından incelendi.

Bulgular: Toplam 18 hastada (\%36) düşük KMY (\%16), osteoporoz $(\% 12)$ ve osteonekroz (\%8) mevcuttu. Osteonekroz sıklığı ve toplam kemik anormallikleri 10 yaş ve üstü çocuklarda anlamlı olarak yüksek bulundu $(p=0,001)$. D vitamini eksikliği olanlarda düşük $B M D$ ve osteonekroz riski daha yüksekti. Gen polimorfizmleri ile ilişki incelendiğinde; sadece Col1A1 Sp1 bağlayıcı bölge gen polimorfizmi ile osteonekroz arasında anlamlı bir ilişki gösterilmiştir.

Sonuç: Sonuç olarak, ALL'den sağ kalan çocuklarda tedaviye bağlı kemik mineral kaybı ve osteonekroz gelişimi sıktır ve bu risk özellikle 10 yaş ve üstü $D$ vitamini eksikliği olan çocuklarda daha yüksektir. Col1A1 Sp1 bağlanma bölgesi gen polimorfizmleri ve osteonekroz arasındaki ilişkiyi araştırmak için ALL'den sağ kalan bireyler üzerinde yapılacak daha geniş çaplı çalışmalara intiyaç vardır.

Anahtar Sözcükler: Akut lenfoblastik lösemi, Kemik mineral dansitesi, Genetik polimorfizm, Osteonekrozis, Osteoporozis 


\section{Introduction}

Cure rates for childhood acute lymphoblastic leukemia (ALL) have approached $90 \%$ with therapeutic advances over the last several decades and the number of survivors has dramatically increased over the last decades $[1,2]$. Many treatment-related long-term complications including impaired physical growth, neurocognitive dysfunction, cardiac abnormalities, secondary neoplasms, low bone mineral density (BMD), osteoporosis, and osteonecrosis have been reported $[3,4,5]$. Bone infiltration of leukemic cells, corticosteroids, methotrexate (MTX) and asparaginase exposure, poor nutrition, low vitamin $D_{\text {, poor }}$ muscle mass, and genetic predisposition contribute to the development or worsening of bone pathologies during or after therapy [3,4]. Multiple clinical risk factors including female sex, administration of dexamethasone, and age have also been identified to have roles in the development of osteoporosis and osteonecrosis $[5,6,7,8,9,10]$.

Corticosteroids, which play a critical role in ALL therapy, directly affect bone and negatively impact the skeleton by altering the hormonal axis, intestinal calcium absorption, and renal excretion of calcium. Multiple candidate gene studies have indicated several polymorphisms in genes putatively related to the development of osteonecrosis, such as SERPINE 1, vitamin D receptor (VDR), and CYP3A4 $[11,12]$.

Vitamin D plays a major role in calcium, phosphorus, and bone metabolism and thus is an important variable in the assessment of bone health [13]. Vitamin D is an important factor that mediates its action in the body through $V D R$, which helps in calcium uptake or bone formation like calcium binding proteins and osteocalcin [14]. The VDR Fok1 locus polymorphism is considered to be a potential regulator of bone and calcium metabolism. Some studies have suggested significant association of Fok1 locus polymorphism with low BMD in girls, whereas others showed no such association $[15,16,17,18]$.

The main component of bone mineral is calcium, and for bone matrix, it is collagen. Osteoporosis is mainly due to the loss of calcium and collagen degradation [19]. The Col1A1 gene encodes the alpha- 1 protein chain of type I collagen, the major protein of bone [20]. Some research has focused on the Col1A1 Sp1-binding site polymorphism and Col1A1 upstream regulatory region single nucleotide polymorphisms, mainly because they can regulate the expression of the Col1A1 gene. These polymorphisms have been significantly associated with low BMD, osteoporosis, and increased fracture risk $[19,20,21,22,23]$.

In this study, we aimed to investigate whether VDR Fok1 and collagen protein Col1A1 Sp1-binding site gene polymorphisms, which are important in bone mineral and matrix formation, have effects on the development of bone abnormalities in childhood ALL survivors.

\section{Materials and Methods}

\section{Study Design and Patients}

Fifty children with ALL who were diagnosed and treated with the ALL Berlin-Frankfurt-Muenster (BFM) 95 protocol [24] between 1998 and 2008 and were followed for at least 7 years after cessation of therapy were enrolled in this study. The control group consisted of 96 healthy children of similar age and sex. The children in the control group had no malignant tumors, chronic diseases, or musculoskeletal system symptoms and also had no evidence of vitamin D deficiency or hypocalcemia.

In the ALL-BFM 95 protocol, patients were stratified according to age, initial white blood cell count, day 8 response to prednisone, immunophenotype, and molecular rearrangements such as $\mathrm{t}(9 ; 22)$ and $\mathrm{t}(4 ; 11)$ into standard-risk (SRG), medium-risk (MRG), and high-risk (HRG) groups. SRG and MRG therapy consisted of an 8-drug induction including prednisone, consolidation with a four-times higher dose of MTX, and an 8-drug reintensification including dexamethasone. HRG patients were treated with a 5-drug induction including prednisone, followed by six intensive multiagent blocks; reintensification was similar to that for the SRG and MRG patients. Maintenance therapy consisted of daily 6-MP and weekly MTX and was continued until 2 years after initial diagnosis. Patients were evaluated for age, sex, risk group, relapse, hemopoietic stem cell transplantation (HSCT), bone metabolism markers (serum calcium, phosphorus, alkaline phosphatase, parathyroid hormone, and 25-hydroxyvitamin D levels), bone changes (clinical and radiographic findings), and Fok1 and Col1A1 Sp1-binding site gene polymorphisms. Vitamin D levels below $20 \mathrm{ng} / \mathrm{mL}$ were considered as deficiency.

In this study, low BMD, osteoporosis, and osteonecrosis were investigated as bone complications. BMD and markers of bone metabolism were all screened routinely before initiation of maintenance treatment and were studied whenever clinically needed. All patients who presented with pain in the joints were examined for bone pathologies while on chemotherapy or during long-term follow-up. All of the data were noted and collected from hospital records. Diagnosis of osteonecrosis had been made based on symptoms, clinical exam findings, and radiographic studies, including plain radiographs and magnetic resonance imaging (MRI). Diagnosis of low BMD and osteoporosis was made based on clinical findings, dual-energy $X$-ray absorptiometry (DEXA), and radiographic studies [25]. The BMDs were measured in $\mathrm{g} / \mathrm{cm}^{2}$ and converted to Z-scores, which represent deviation from age-matched and sex-matched normative BMDs. Mean values and standard deviations (SDs) were calculated for each patient. We defined osteoporosis as a BMD $\leq 2$ SD below the mean $(Z \leq-2)$ and low BMD as a BMD that is abnormal but not $>2$ SD below the mean $(-2>Z \leq 0)$ [36]. The term "osteopenia" was not used since "low BMD" is the preferred term for pediatric DEXA reports [26]. In our hospital 
DEXA results were assessed by measuring mineral density in the L1-L4 vertebra corpus; therefore, the Z-scores in the definition of osteoporosis and low BMD were obtained by this regional analysis. The proximal femur or hip region was included according to clinical and radiologic findings.

Informed consent was obtained from the parents of all patients. This study was approved by the Ethics Committee of the Dokuz Eylül University Faculty of Medicine and the work described was carried out in accordance with the Declaration of Helsinki for experiments involving humans.

\section{Genotyping}

Peripheral blood samples from all individuals were collected into sterile tubes containing $0.1 \mathrm{M}$ EDTA and stored at $-20^{\circ} \mathrm{C}$. Genomic DNA was extracted using the NucleoSpin Blood Extraction Kit (Macherey-Nagel, Duren, Germany). The genotypes were detected by polymerase chain reaction-restriction fragment length polymorphism (PCR-RFLP) analysis. The polymorphic locus was amplified using 5'-AGCTGGCCCTGGCACTGACTCTGCTCT-3' as the forward and 5'-ATGGAAACACCTTGCTTCTTCTCCCTC-3' as the reverse primer. PCR (Thermocycler; MJ Research PTC-200) was performed with 35 cycles by the following steps: denaturation at $94{ }^{\circ} \mathrm{C}$ for $30 \mathrm{~s}$, annealing at $61^{\circ} \mathrm{C}$ for $30 \mathrm{~s}$, and extension at 72 ${ }^{\circ} \mathrm{C}$ for $1 \mathrm{~min}$. After amplification the 256-bp PCR product was digested with FastDigest Fok1 restriction endonuclease for 5 min. Digested products were analyzed on 2\% agarose gel stained with ethidium bromide. The sizes of the bands were estimated using a 100-bp ladder. The genotyping was done on the basis of the presence or absence of the Fok1 site as follows: FF=265 bp; $\mathrm{Ff}=265 \mathrm{bp}, 169 \mathrm{bp}$, and $96 \mathrm{bp}$; and ff=169 bp and $96 \mathrm{bp}$ lengths, respectively. The absence of a restriction site is represented by $F$ while the presence of a restriction site is represented by $f$.

The guanine $(\mathrm{G})$ to thymidine $(\mathrm{T})$ gene polymorphism in the Sp1binding site in the first intron of the Col1A1 gene was determined by a PCR-based method. The primers (MBI Fermentas, Lithuania) used for PCR to amplify Col1A1 gene fragments were as follows; forward primer 5'-TAACTCTGGACTA TाGCGGACTITGG-3' and reverse primer 5'-GTCCAGCCCTCATCCTGGCC-3' for the Sp1 restriction site DNA. Genotypes for Col1A1 Sp1 polymorphisms were classified as $\mathrm{G} / \mathrm{G}$ homozygotes (SS), G/T heterozygotes (Ss), and $\mathrm{T} / \mathrm{T}$ homozygotes (ss).

\section{Statistical Analysis}

In statistical analysis, SPSS 23.0 and Number Cruncher Statistical System 2007 were used. Categorical variables were defined with frequency and percentage; continuous variables were given as mean deviation in parametric conditions and median (min., max.) in nonparametric conditions. In the analytical review of the data, the effects of Fok 1 and Col1A1 gene polymorphisms and other characteristics of the patient on low BMD, osteoporosis, osteonecrosis, and categorical variables were investigated by chi-square analysis. In chi-square analysis, Fisher's exact test, Pearson's chi-square test, the continuity correction test, and the Fisher-Freeman-Halton test were applied according to expected values and group numbers. Statistical significance was accepted at $p<0.05$.

\section{Results}

The general characteristics of the patients are shown in Table 1. The median age at diagnosis was 61.5 months (min. 11, max. 204 months). Five (10\%) patients had to be treated with HSCT. The median age of the patients at the time of first DEXA was 96 months (min. 35, max. 196 months). The median and mean DEXA Z-scores were 0.145 and $0.63 \mathrm{~g} / \mathrm{cm}^{2}$, respectively. Low BMD, osteoporosis, and osteonecrosis were present in 18 patients (36\%) (Table 2). Lumbosacral vertebras, femur heads, knees, and sacroiliac joints were the most affected areas on MRI. Osteonecrosis was present in one patient at the bilateral sacroiliac joints, one patient at the L4-L5 area, and two patients at the head of the left and right femur, respectively.

The sex distribution among patients with bone features was not statistically significant. Rates of osteonecrosis and total bone changes were significantly higher in patients aged $\geq 10$ years ( $p=0.001, p=0.029$, respectively) (Table 2 ).

When the bone metabolism markers were examined, hypocalcemia was observed in 7 patients, hypophosphatemia

\begin{tabular}{|c|c|c|}
\hline & $\mathbf{n}$ & $\%$ \\
\hline \multicolumn{3}{|l|}{ Sex } \\
\hline Male & 25 & 50 \\
\hline Female & 25 & 50 \\
\hline \multicolumn{3}{|l|}{ Immunophenotypes } \\
\hline Pre-B-cell ALL & 46 & 92 \\
\hline T-cell ALL & 4 & 8 \\
\hline \multicolumn{3}{|l|}{ Age (years) } \\
\hline $0-10$ & 39 & 78 \\
\hline$\geq 10$ & 11 & 22 \\
\hline \multicolumn{3}{|l|}{ Risk groups } \\
\hline SRG & 12 & 24 \\
\hline MRG & 28 & 56 \\
\hline HRG & 10 & 20 \\
\hline \multicolumn{3}{|l|}{ Relapse } \\
\hline Yes & 3 & 6 \\
\hline No & 47 & 94 \\
\hline \multicolumn{3}{|l|}{ Results } \\
\hline Complete remission & 47 & 94 \\
\hline Exitus & 3 & 6 \\
\hline \multicolumn{3}{|c|}{$\begin{array}{l}\text { SRG: Standard-risk group, MRG: medium-risk group, HRG: high-risk group, ALL: acute } \\
\text { lymphoblastic leukemia. }\end{array}$} \\
\hline
\end{tabular}


was observed in 14 patients, and alkaline phosphatase elevation was observed in 12 patients. No significant difference was found in terms of risk of developing low BMD, osteoporosis, osteonecrosis, and total bone changes according to these markers. However, the risk of low BMD, osteonecrosis, and total bone changes was higher in those with vitamin $D$ deficiency and this was statistically significant $(p=0.003, p=0.004, p=0.001$, respectively) (Table 3 ). There was no relationship between any of these bone changes and parameters that could change the duration of treatment, such as ALL risk groups, relapse status, and HSCT. Only one patient had osteonecrosis in our HSCT group.

Distribution of Fok1 and Col1A1 Sp1-binding site gene polymorphisms in both groups is shown in Table 4. Fok1 polymorphism shows a significant difference between patients and the control group. In terms of the mentioned bone changes, Col1A1 gene and Fok1 Sp1-binding site gene polymorphisms did not show a significant correlation between BMD values and Z-scores. The distribution of Fok1 and Col1A1 Sp1-binding site gene polymorphisms according to low BMD, osteoporosis, and osteonecrosis is shown in Table 5. Only gene polymorphism in the Sp1-binding site of Col1A1 showed a significant association in patients with osteonecrosis $(p=0.045)$.
On follow-up, 2 of the 18 patients needed surgical operation; others received calcium and vitamin D supplements with or without bisphosphonate replacement therapy for better quality of life. All of the patients with low BMD and osteoporosis exhibited an increase in BMD values and Z-scores in the longterm follow-up period.

\section{Discussion}

In children who had completed therapy for ALL, the prevalence of BMD abnormalities was reported to be as high as 93\% and the incidence for asymptomatic osteonecrosis was found to vary between $15 \%$ and $38 \%$ among survivors $[27,28,29]$. Recently, Vitanza et al. [27] demonstrated that $46.6 \%$ of children exhibited osteoporosis in at least one anatomic site at some time during the first 6 years after chemotherapy. In our study, low BMD (32\%), osteoporosis (24\%), and osteonecrosis $(16 \%)$ were present in 18 out of 50 patients (36\%) who were followed for more than 7 years for these features. Lumbosacral vertebras, femur heads, knees, and sacroiliac joints were the most affected areas on $\mathrm{MRI}$, as identified in the literature $[28,29,30]$. Prior studies reported multiple clinical risk factors for the development of osteonecrosis, including female sex, older age, administration of 3 weeks of continuous rather than alternate week dexamethasone during delayed intensification,

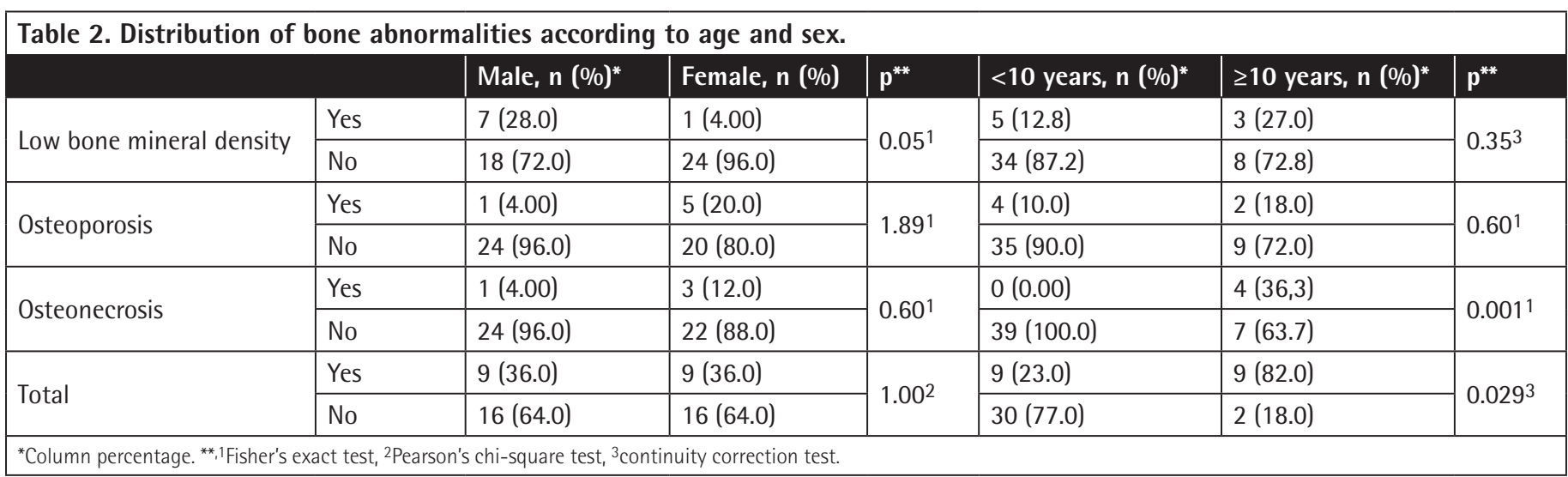

\begin{tabular}{|c|c|c|c|c|}
\hline & & \multicolumn{3}{|c|}{ Vitamin D deficiency } \\
\hline & & Yes, n (\%)* & No, n $(\%)^{*}$ & $\mathbf{p}^{* *}$ \\
\hline \multirow{2}{*}{$\begin{array}{l}\text { Low bone mineral } \\
\text { density }\end{array}$} & Yes & $4(66.7)$ & $4(9.1)$ & \multirow{2}{*}{0.003} \\
\hline & No & $2(33.3)$ & $40(90.9)$ & \\
\hline \multirow{2}{*}{ Osteoporosis } & Yes & 1 (16.7) & $5(11.4)$ & \multirow{2}{*}{0.556} \\
\hline & No & $5(83.3)$ & 39 (88.6) & \\
\hline \multirow{2}{*}{ Osteonecrosis } & Yes & $3(50.0)$ & $1(2.3)$ & \multirow{2}{*}{0.004} \\
\hline & No & $3(50.0)$ & $43(97.7)$ & \\
\hline \multirow{2}{*}{ Total } & Yes & $8(100)$ & $10(22.7)$ & \multirow{2}{*}{0.001} \\
\hline & No & $0(0.00)$ & $34(77.3)$ & \\
\hline
\end{tabular}

Table 4. Distribution of Fok1 polymorphism and Col1A1 polymorphism in patients and control group.

\begin{tabular}{|c|c|c|c|}
\hline $\begin{array}{l}\text { Gene } \\
\text { polymorphisms }\end{array}$ & Patients, n (\%) ${ }^{*}$ & Controls, n (\%) & $\mathbf{p}^{* *}$ \\
\hline \multicolumn{4}{|l|}{ Fok1 genotypes } \\
\hline $\mathrm{ff}$ & $4(8)$ & $18(18.8)$ & \multirow{3}{*}{0.003} \\
\hline $\mathrm{Ff}$ & $23(46)$ & $59(61.5)$ & \\
\hline $\mathrm{FF}$ & $23(46)$ & $19(19.8)$ & \\
\hline \multicolumn{4}{|c|}{ Col1A1 genotypes } \\
\hline $\mathrm{GG}$ & $31(62)$ & $53(55.2)$ & \multirow{3}{*}{0.667} \\
\hline GT & $13(26)$ & $27(28.1)$ & \\
\hline$\pi$ & $6(12)$ & $16(16.7)$ & \\
\hline
\end{tabular}




\begin{tabular}{|c|c|c|c|c|c|c|c|c|c|}
\hline & & \multicolumn{4}{|c|}{ Fok1 gene polymorphisms } & \multicolumn{4}{|c|}{ Col1A1 gene polymorphisms } \\
\hline & & ff, n (\%)* & Ff, n (\%)* & FF, n (\%)* & $\mathrm{p}^{* *}$ & GG, n (\%)* & GT, n (\%)* & $\Pi$, n (\%)* & $\mathbf{p}^{* *}$ \\
\hline \multirow{2}{*}{$\begin{array}{l}\text { Low bone mineral } \\
\text { density }\end{array}$} & Yes & $0(0.0)$ & $6(26.0)$ & $2(8.60)$ & \multirow{2}{*}{0.271} & $5(16.1)$ & $3(23.0)$ & $0(0.0)$ & \multirow{2}{*}{0.537} \\
\hline & No & $4(100)$ & $17(74.0)$ & $21(91.4)$ & & $26(83.9)$ & $10(77.0)$ & $6(100)$ & \\
\hline \multirow{2}{*}{ Osteoporosis } & Yes & $1(25.0)$ & $1(4.30)$ & $4(17.4)$ & \multirow{2}{*}{0.243} & $3(9.70)$ & $1(7.70)$ & $2(33.3)$ & \multirow{2}{*}{0.274} \\
\hline & No & $3(75.0)$ & $22(95.7)$ & $19(82.6)$ & & $28(90.3)$ & $12(92.3)$ & $4(66.7)$ & \\
\hline \multirow{2}{*}{ Osteonecrosis } & Yes & $1(25.0)$ & $2(8.60)$ & $1(4.30)$ & \multirow{2}{*}{0.368} & $1(3.20)$ & $1(7.70)$ & $2(33.3)$ & \multirow{2}{*}{0.045} \\
\hline & No & $3(75.0)$ & $21(91.4)$ & $22(95.7)$ & & $30(96.8)$ & $12(92.3)$ & $4(66.7)$ & \\
\hline \multirow{2}{*}{ Total } & Yes & $2(50.0)$ & $8(34.8)$ & $6(26.1)$ & \multirow{2}{*}{0.597} & $9(29.0)$ & $4(30.7)$ & $3(50.0)$ & \multirow{2}{*}{0.537} \\
\hline & No & $2(50.0)$ & $15(65.2)$ & $17(73.9)$ & & $22(71.0)$ & $9(69.3)$ & $3(50.0)$ & \\
\hline
\end{tabular}

and intensive therapy $[9,10,31,32,33]$. We found no relationship between these bone changes and specific risk factors such as sex distribution, duration of treatment, ALL risk groups, and relapse status. As reported in the literature, the risk of osteonecrosis and other bone complications was significantly higher in patients aged $\geq 10$ years in our study. Age remains the strongest and most consistently identified factor, with patients 10 to 20 years old at greatest risk $[5,6,7,8,9,10,27,33]$. In a retrospective report on the ALL-BFM-95 trial, the osteonecrosis incidence was reported to be $8.9 \%$ in patients aged $\geq 10$ years and even higher in those $\geq 15$ years (16.7\%) [9]. The results also did not show female sex as a significant risk factor for developing osteonecrosis and higher incidences were found to be accompanied by higher total steroid doses. For the first time, Krull et al. [30] recently demonstrated that asymptomatic osteonecrosis develops independently of radiological leukemic infiltration of bone in adolescents with ALL.

Different studies have reported a list of genes effective on osteoporosis, such as VDR, Col1A1, estrogen receptor alpha, interleukin-6, and LDL receptor-related protein $5[16,17]$. The relationships between Col1A1 Sp1 polymorphism and BMD were investigated among various populations. Previous studies have shown associations between Col1A1 Sp1 polymorphisms and low BMD, osteoporosis, and increased fracture risk $[20,21,22,23,34,35]$, while some have not reached statistical significance $[36,37]$. In healthy prepubertal children, there have only been a small number of studies examining possible effects of Col1A1 gene polymorphisms on BMD $[38,39,40]$. In our study, only gene polymorphism in the Sp1-binding site of Col1A1 showed a significant association in ALL patients with osteonecrosis, but not for other bone abnormalities. Since the main component of bone matrix is collagen, this may be an important finding that has to be assessed in a larger group of ALL survivors.

VDR Fok1 locus polymorphism is considered to be a potential regulator of bone and calcium metabolism. Studies on VDRgene polymorphisms of the Fok 1 locus and its associations with bone mass in children have shown varied results $[17,18,41,42,43]$. Of note, Fok1 locus polymorphism was found to be significantly different between patients and the control group in our study. This may have resulted from the relatively limited number of subjects in both groups. We found no significant association between Fok1 genotypes and low BMD, osteoporosis, or osteonecrosis in children with ALL. In our study, the risk of low BMD, osteonecrosis, and total bone changes was higher in patients with vitamin $D$ deficiency. Potential risk factors for decreased vitamin $D$ in survivors of childhood cancer include poor diet, more time spent indoors, less physical activity, and administration of chemotherapy, steroids, and radiation therapy [44]. The prevalence of decreased vitamin $D$ in children with cancer is high (29\%-35\%) but quite similar to what has been demonstrated in the general population $[44,45]$. A randomized double-blind study showed that nutritional counseling and vitamin D and calcium supplementation for 2 years offered no benefit for improving BMD among adolescent and young adult survivors of ALL [46]. Recently, a similar result was reported from a Turkish study group [47]. Depending on these findings, alternative and more aggressive strategies are needed to prevent these patients from experiencing bone complications.

\section{Conclusion}

The development of therapy-induced bone mineral loss and osteonecrosis in children with ALL is frequent and the risk is higher especially in children aged $\geq 10$ years and with vitamin D deficiency. The association between Col1A1 Sp1-binding site gene polymorphisms and osteonecrosis has to be assessed in a larger group of ALL survivors. Studies investigating the possible underlying genetic susceptibilities to certain complications are important not only for better management of complications but also for development of new individual patient-specific treatment modalities. 


\section{Ethics}

Ethics Committee Approval: This study was approved by the Ethics Committee of the Dokuz Eylül University Faculty of Medicine.

Informed Consent: Informed consent was obtained from parents or legal guardians before enrollment in the study.

\section{Authorship Contributions}

Surgical and Medical Practices: M.E., Ö.T., Ş.Y., D.K., H.Ö.; Concept: M.E., Ö.T., H.Ö.; Design: M.E., Ö.T., S.K., H.Ö.; Data Collection or Processing: M.E., Ş.Y., D.K., B.E.F.; Analysis or Interpretation: M.E., Ö.T., S.K., Ş.Y., H.Ö.; Literature Search: M.E., Ö.T., S.K., H.Ö.; Writing: M.E., Ö.T., S.K., H.Ö.

Conflict of Interest: The authors of this paper have no conflicts of interest, including specific financial interests, relationships, and/or affiliations relevant to the subject matter or materials included.

\section{References}

1. Schrappe M, Möricke A, Reiter A, Henze G, Welte K, Gadner H, Ludwig WD, Ritter J, Harbott J, Mann G, Klingebiel T, Gruhn B, Niemeyer C, Kremens B, Niggli F, Debatin KM, Ratei R, Stanulla M, Beier R, Cario G, Schrauder A, Zimmermann M. Key treatment questions in childhood acute lymphoblastic leukemia: results in 5 consecutive trials performed by the ALL BFM study group from 1981 to 2000. Klin Padiatr 2013;225(Suppl 1):62-72.

2. Conter $V$, Bartram $C R$, Valsecchi $M G$, Schrauder $A$, Panzer-Grümayer $R$, Möricke A, Aricò M, Zimmermann M, Mann G, De Rossi G, Stanulla $M$, Locatelli F, Basso G, Niggli F, Barisone E, Henze G, Ludwig WD, Haas OA, Cazzaniga G, Koehler R, Silvestri D, Bradtke J, Parasole R, Beier R, van Dongen $\mathrm{JJ}$, Biondi A, Schrappe M. Molecular response to treatment redefines all prognostic factors in children and adolescents with B-cell precursor acute lymphoblastic leukemia: results in 3184 patients of the AIEOP BFM ALL 2000 study. Blood 2010;115:3206-3214.

3. Haddy TB, Mosher RB, Reaman GH. Late effects in long-term survivors after treatment for childhood acute leukemia. Clin Pediatr (Phila) 2009;48:601608.

4. Mandel K, Atkinson S, Barr RD, Pencharz P. Bone morbidity in childhood acute lymphoblastic leukemia. J Clin Oncol 2004;22:1215-1221.

5. Padhye B, Dalla-Pozza L, Little D, Munns C. Incidence and outcome of osteonecrosis in children and adolescents after intensive therapy for acute lymphoblastic leukemia (ALL). Cancer Med 2016;5:960-967.

6. te Winkel ML, Pieters R, Hop WC, Roos JC, Bökkerink JP, Leeuw JA, Bruin MC, Kollen WJ, Veerman AJ, de Groot-Kruseman HA, van der Sluis IM, van den Heuvel-Eibrink MM. Bone mineral density at diagnosis determine fracture rates in children with acute lymphoblastic leukemia treated according to the DCOG-ALL9 protocol. Bone 2014;59:223-228.

7. Karol SE, Mattano LA Jr, Yang W, Maloney KW, Smith C, Liu C, Ramsey LB, Fernandez CA, Chang TY, Neale G, Cheng C, Mardis E, Fulton R, Scheet $P$, San Lucas FA, Larsen EC, Loh ML, Raetz EA, Hunger SP Devidas M, Relling MV. Genetic risk factors for the development of osteonecrosis in children under age 10 treated for acute lymphoblastic leukemia. Blood 2016;127:558-564.

8. Kunstreich M, Kummer S, Laws HJ, Borkhardt A, Kuhlen M. Osteonecrosis in children with acute lymphoblastic leukemia. Haematologica 2016;101:12951305.

9. Bürger B, Beier R, Zimmermann M, Beck JD, Reiter A, Schrappe M. Osteonecrosis: a treatment related toxicity in childhood acute lymphoblastic leukemia (ALL)-experiences from trial ALL-BFM 95. Pediatr Blood Cancer 2005:44:220-225.

10. Patel B, Richards SM, Rowe JM, Goldstone AH, Fielding AK. High incidence of avascular necrosis in adolescents with acute lymphoblastic leukaemia: a UKALL XII analysis. Leukemia 2008;22:308-312.

11. French D, Hamilton LH, Mattano LA Jr, Sather HN, Devidas M, Nachman JB, Relling MV; Children's Oncology Group. A PAI-1 (SERPINE1) polymorphism predicts osteonecrosis in children with acute lymphoblastic leukemia: a report from the Children's Oncology Group. Blood 2008;111:4496-4499.

12. Asano $T$, Takahashi KA, Fujioka $M$, Inoue $S$, Satomi $Y$, Nishino $H$, Tanaka $T$, Hirota Y, Takaoka K, Nakajima S, Kubo T. Genetic analysis of steroid-induced osteonecrosis of the femoral head. J Orthop Sci 2003;8:329-333.

13. Lehtonen-Veromaa MK, Möttönen $\Pi$, Nuotio IO, Irjala KM, Leino AE, Viikari JS. Vitamin $D$ and attainment of peak bone mass among peripubertal Finnish girls: a 3-y prospective study. Am J Clin Nutr 2002; 76:1446-1453.

14. Bunce $C M$, Brown G, Hewison M. Vitamin D and hematopoiesis. Trends Endocrinol Metab 1997;8:245-251.

15. Morrison NA, Qi JC, Tokita A, Kelly PJ, Crofts L, Nguyen TV, Sambrook PN, Eisman JA. Prediction of bone density from vitamin D receptor alleles. Nature 1994;367:284-287.

16. Katsumata $K$, Nishizawa $K$, Unno A, Fujita Y, Tokita A. Association of gene polymorphisms and bone density in Japanese girls. J Bone Miner Metab 2002;20:164-169.

17. Arabi A, Mahfoud Z, Zahed L, El-Onsi L, El-Hajj FG. Effect of age, gender and calciotropic hormones on the relationship between vitamin $D$ receptor gene polymorphisms and bone mineral density. Eur J Clin Nutr 2010;64:383-391.

18. Laaksonen MM, Kärkkäinen MU, Outila TA, Rita HJ, Lamberg Allardt CJ. Vitamin D receptor gene start codon polymorphism (Fokl) is associated with fore arm BMD and calcaneal ultrasound in Finnish adolescent boys but not in girls. J Bone Miner Metab 2004;22:479-485.

19. Blades HZ, Arundel P, Carlino WA, Dalton A, Crook JS, Freeman JV, Bishop NJ. Collagen gene polymorphisms influence fracture risk and bone mass acquisition during childhood and adolescent growth. Bone 2010;47:989994.

20. Mann V, Hobson EE, Li B, Stewart TL, Grant SF, Robins SP, Aspden RM, Ralston SH. A COL1A1 Sp1 binding site polymorphism predisposes to osteoporotic fracture by affecting bone density and quality. J Clin Invest 2001;107:899907.

21. Grant SF, Reid DM, Blake G, Herd R, Fogelman I, Ralston SH. Reduced bone density and osteoporosis associated with a polymorphic Sp1 binding site in the collagen type I alpha 1 gene. Nat Genet 1996;14:203-205.

22. Ralston SH. Genetics of osteoporosis. Ann New York Acad Sci 2010;1192:181189.

23. Mann V, Hobson EE, Li B, Stewart TL, Grant SF, Robins SP, Aspden RM, Ralston $\mathrm{SH}$. A COL1A1 Sp1 binding site polymorphism predisposes to osteoporotic fractures by affecting bone density and quality. J Clin Invest 2001;107:899907.

24. Möricke A, Reiter A, Zimmermann M, Gadner H, Stanulla M, Dördelmann M, Löning L, Beier R, Ludwig WD, Ratei R, Harbott J, Boos J, Mann G, Niggli $F$, Feldges $A$, Henze $G$, Welte $K$, Beck JD, Klingebiel T, Niemeyer C, Zintl $F$, Bode $U$, Urban $C$, Wehinger $H$, Niethammer D, Riehm $H$, Schrappe $M$; German-Austrian-Swiss ALL-BFM Study Group. Risk-adjusted therapy of acute lymphoblastic leukemia can decrease treatment burden and improve survival: treatment results of 2169 unselected pediatric and adolescent patients enrolled in the trial ALL-BFM 95. Blood 2008;111:4477-4489.

25. Gordon CM, Bachrach LK, Carpenter TO, Crabtree N, El-Hajj Fuleihan G, Kutilek S, Lorenc RS, Tosi LL, Ward KA, Ward LM, Kalkwarf HJ. Dual energy $\mathrm{X}$-ray absorptiometry interpretation and reporting in children and adolescents: the 2007 ISCD Pediatric Official Positions. J Clin Densitom 2008:11:43-58. 
26. Crabtree NJ, Arabi A, Bachrach LK, Fewtrell M, El-Hajj Fuleihan G, Kecskemethy $\mathrm{HH}$, Jaworski $\mathrm{M}$, Gordon $\mathrm{CM}$; International Society for Clinical Densitometry. Dual-energy $\mathrm{X}$-ray absorptiometry interpretation and reporting in children and adolescents: the revised 2013 ISCD Pediatric Official Positions. J Clin Densitom 2014;17:225-242.

27. Vitanza NA, Hogan LE, Zhang G, Parker RI. The Progression of Bone Mineral Density Abnormalities After Chemotherapy for Childhood Acute Lymphoblastic Leukemia. J Pediatr Hematol Oncol 2015;37:356-361.

28. Ojala $A E$, Pääkkö $E$, Lanning $F P$, Lanning $M$. Osteonecrosis during the treatment of childhood acute lymphoblastic leukemia: a prospective MRI study. Med Pediatr Oncol 1998;32:11-17.

29. Ribeiro RC, Fletcher BD, Kennedy $W$, Harrison $\mathrm{PL}$, Neel MD, Kaste $\mathrm{SC}$, Sandlund JT, Rubnitz JE, Razzouk BI, Relling MV, Pui CH. Magnetic resonance imaging detection of avascular necrosis of the bone in children receiving intensive prednisone therapy for acute lymphoblastic leukemia or non-Hodgkin lymphoma. Leukemia 2001;15:891-897.

30. Krull K, Kunstreich M, Klasen-Sansone J, Kloetgen A, Gruener F, Escherich G, Bleckmann K, Moericke A, Schrappe M, Jorch N, Steinbach D, Classen CF, Guggemos A, Kolb R, Klee D, Borkhardt A, Kuhlen M. Osteonecrosis develops independently from radiological leukemic infiltration of bone in adolescents with acute lymphoblastic leukemia - first findings of the OPAL trial. Leuk Lymphoma 2017;58:2363-2369.

31. Mattano LA Jr, Sather HN, Trigg ME, Nachman JB. Osteonecrosis as a complication of treating acute lymphoblastic leukemia in children: a report from the Children's Cancer Group. J Clin Oncol 2000;18:3262-3272.

32. Kawedia JD, Kaste SC, Pei D, Panetta JC, Cai X, Cheng C, Neale G, Howard SC, Evans WE, Pui CH, Relling MV. Pharmacokinetic, pharmacodynamic, and pharmacogenetic determinants of osteonecrosis in children with acute lymphoblastic leukemia. Blood 2011;117:2340-2347.

33. Mattano LA Jr, Devidas M, Nachman JB, Sather HN, Hunger SP, Steinherz PG, Gaynon PS, Seibel NL; Children's Oncology Group. Effect of alternate week versus continuous dexamethasone scheduling on the risk of osteonecrosis in paediatric patients with acute lymphoblastic leukaemia: results from the CCG-1961 randomised cohort trial. Lancet Oncol 2012;13:906-915.

34. Falcón-Ramírez E, Casas-Avila L, Miranda A, Diez P, Castro C, Rubio J, Gómez R, Valdés-Flores M. MSp1 polymorphism in collagen I $\alpha 1$ gene is associated with osteoporosis in lumbar spine of Mexican women. Mol Biol Rep 2011;38:2987-2992.

35. MacDonald HM, McGuigan FA, New SA, Campbell MK, Golden MH, Ralston $\mathrm{SH}$, Reid DM. COL1A1 Sp1 polymorphism predicts perimenopausal and early postmenopausal spinal bone loss. J Bone Miner Res 2001;16:16341641.

36. Ashford RU, Luchetti M, McCloskey EV, Gray RL, Pande KC, Dey A, Kayan K, Ralston SH, Kanis JA. Studies of bone density, quantitative ultrasound, and vertebral fractures in relation to collagen type I alpha 1 alleles in elderly women. Calcif Tissue Int 2001;68:348-351.

37. Wynne F, Drummond F, O'Sullivan K, Daly M, Shanahan F, Molloy MG, Quane $K A$. Investigation of the genetic influence of the OPG, VDR (Fok1), and COL1A1 Sp1 polymorphisms on BMD in the Irish population. Calcif Tissue Int 2002;71:26-35.

38. Suuriniemi $M$, Kovanen $V$, Mahonen $A$, Alén $M$, Wang $Q$, Lyytikäinen $A$, Cheng S. COL1A1 Sp1 polymorphism associates with bone density in early puberty. Bone 2006;39:591-597.

39. Willing MC, Torner JC, Burns TL, Janz KF, Marshall T, Gilmore J, Deschenes SP, Warren JJ, Levy SM. Gene polymorphisms, bone mineral density and bone mineral content in young children: the lowa Bone Development Study. Osteoporos Int 2003;14:650-658.

40. van der Sluis IM, de Muinck Keizer-Schrama SM, Pols HA, Lequin $M H$ Krenning EP, Uitterlinden AG. Colçlagen lalpha1 polymorphism is associated with bone characteristics in Caucasian children and young adults. Calcif Tissue Int 2002;71:393-399.

41. Cusack S, Mølgaard C, Michaelsen KF, Jakobsen J, Lamberg-Allardt CJ, Cashman KD. Vitamin D and estrogen receptor-alpha genotype and indices of bone mass and bone turnover in Danish girls. J Bone Miner Metab 2006;24:329-336.

42. Abrams SA, Griffin IJ, Hawthorne KM, Chen Z, Gunn SK, Wilde M, Darlington G, Shypailo RJ, Ellis KJ. Vitamin D receptor Fok1 polymorphisms affect calcium absorption, kinetics, and bone mineralization rates during puberty. J Bone Miner Res 2005;20:945-953.

43. Sanwalka N, Khadilkar A, Chiplonkar S, Khatod K, Phadke N, Khadilkar V. Influence of vitamin D receptor gene Fok1 polymorphism on bone mass accrual post calcium and vitamin D supplementation. Indian J Pediatr 2015;82:985-990.

44. Choudhary A, Chou J, Heller G, Sklar C. Prevalence of vitamin D insufficiency in survivors of childhood cancer. Pediatr Blood Cancer 2013;60:1237-1239.

45. Simmons JH, Chow EJ, Koehler E, Esbenshade A, Smith LA, Sanders J, Friedman D. Significant 25-hydroxyvitamin D deficiency in child and adolescent survivors of acute lymphoblastic leukemia: Treatment with chemotherapy compared with allogenic stem cell transplant. Pediatr Blood Cancer 2011;56:1114-1119.

46. Kaste SC, Qi A, Smith K, Surprise H, Lovorn E, Boyett J, Ferry RJ Jr, Relling MV, Shurtleff SA, Pui CH, Carbone L, Hudson MM, Ness KK. Calcium and cholecalciferol supplementation provides no added benefit to nutritional counseling to improve bone mineral density in survivors of childhood acute lymphoblastic leukemia (ALL). Pediatr Blood Cancer 2014;61:885-893.

47. Demirsoy U, Sarper N, Aylan Gelen S, Zengin E, Kum T, Demir H. The Association of Oral Vitamin D and Calcium Supplementation With Bone Mineral Density in Pediatric Acute Lymphoblastic Leukemia Patients. J Pediatr Hematol Oncol 2017;39:287-292. 